Silva, C.B.; Amaral, R.F. Possibilidades de inserção produtiva para comunidades do entorno de Unidades de Conservação através de trilhas ecológicas. Anais do VIII Congresso Nacional de Ecoturismo e do IV Encontro Interdisciplinar de Ecoturismo em Unidades de Conservação. Revista Brasileira de Ecoturismo, São Paulo, v.4, n.4, 2011, p. 585.

\title{
POSSIBILIDADES DE INSERÇÃO PRODUTIVA PARA COMUNIDADES DO ENTORNO DE UNIDADES DE CONSERVAÇÃO ATRAVÉS DE TRILHAS ECOLÓGICAS
}

\author{
Clébia Bezerra da Silva*, Ricardo Farias do Amaral* \\ *Universidade Federal do Rio Grande do Norte \\ E-mails: clebiabsilva@yahoo.com.br, ric@ufrnet.br
}

O turismo é uma atividade sustentável quando ecologicamente sustentável, a longo prazo, viável economicamente, ética e socialmente equitativo para as comunidades locais. Em se tratando de comunidades do entorno de Unidade de Conservação, a sustentabilidade é condição sine qua non para seu desenvolvimento. Sobre este prima, foi desenvolvido o Projeto Caminhos de Maracajaú, com o apoio da PróReitoria de Extensão da UFRN. Um dos objetivos do projeto era de identificar novas possibilidades de passeios turísticos e inserir as comunidades do entorno da Área de Proteção Ambiental dos Recifes de Corais (APARC), nesse novo contexto. A comunidade de Maracajaú, circunvizinha à APARC, está situada no município de Maxaranguape, $70 \mathrm{~km}$ de Natal, com aproximadamente 2500 habitantes. As trilhas ecológicas identificadas são uma alternativa a atividade de mergulho, desenvolvida na APARC, e feita quase que exclusivamente por empresas. Para uma das trilhas foram organizadas excursões no intuito de testar sua atratividade, possibilidades de interpretação ambiental e inserção da comunidade. O pacote oferecia traslado NatalMaracajaú, café da manhã, lanche, guiamento, almoço. A dinâmica do passeio foi a seguinte: café da amanhã na padaria de Maracajaú; visita à sede da APA dos Recifes de Corais, para serem dadas as informações sobre a comunidade, o projeto, as trilhas e as condutas permitidas.Nesse local havia, também, artesões locais que foram convidados a exporem seus produtos. Após essa etapa, iniciava-se a trilha, com duração média de $3 \mathrm{~h}$. O guiamento do grupo era de responsabilidade de orientadores turísticos locais e equipe do projeto, um orientador para cada sete turistas. A trilha culmina na lagoa do Baião Grande, onde havia um lanche para os turistas, que era levado por um carroceiro. Tanto os orientadores e carroceiros receberam pelos seus serviços. O seguinte ponto de parada era o da Casa de Farinha, onde já havia um morador esperando pelos turistas com cocos, para vender. Ao fim da trilhas, todos foram almoçar em restaurante de um morador local, expescador. À tarde o tempo era liberado para os turistas fazerem o que quisessem. Eles foram fazer passeios oferecidos pelos orientadores turísticos, em sua maioria. Os resultados comprovaram a capacidade que o turismo tem de possibilitar a inserção produtiva e econômica de pessoas em vulnerabilidade social aliadas à emancipação social e preservação ambiental.

Palavras-chave: Maracajaú; Unidades de Conservação; Comunidades do Entorno. 